\title{
Lactoferrin affects rhinovirus B-14 entry into H1-HeLa cells
}

\author{
Caio Bidueira Denani ${ }^{1} \cdot$ Antonio Real-Hohn ${ }^{2}$ (D) Carlos Alberto Marques de Carvalho ${ }^{3,4}$. \\ Andre Marco de Oliveira Gomes ${ }^{5,6} \cdot$ Rafael Braga Gonçalves $^{7}$
}

Received: 2 June 2020 / Accepted: 24 December 2020 / Published online: 19 February 2021

(c) The Author(s) 2021

\begin{abstract}
Lactoferrin is part of the innate immune system, with antiviral activity against numerous DNA and RNA viruses. Rhinoviruses, the leading cause of the common cold, are associated with exacerbation of respiratory illnesses such as asthma. Here, we explored the effect of bovine lactoferrin (BLf) on RV-B14 infectivity. Using different assays, we show that the effect of BLf is strongest during adhesion of the virus to the cell and entry. Tracking the internalisation of BLf and virus revealed a degree of colocalisation, although their interaction was only confirmed in vitro using empty viral particles, indicating a possible additional influence of BLf on other infection steps.
\end{abstract}

\section{Introduction}

The antiviral effect of the $80-\mathrm{kDa}$ iron-binding glycoprotein lactoferrin (Lf) has been investigated for decades [1]. More recently, the effect of bovine Lf (BLf) on infection by different enteroviruses was also accessed. In vitro studies demonstrated that the presence of BLf during the viral

Handling Editor: Zhenhai Chen.

Antonio Real-Hohn

antonio.hohn@meduniwien.ac.at

1 Instituto de Tecnologia em Imunobiológicos, Fundação Oswaldo Cruz, Rio de Janeiro, RJ, Brazil

2 Center for Medical Biochemistry, Max Perutz Laboratories, Medical University of Vienna, Vienna Biocenter, Vienna, Austria

3 Departamento de Patologia, Centro de Ciências Biológicas e da Saúde, Universidade do Estado do Pará, Belém, PA, Brazil

4 Centro Universitário Metropolitano da Amazônia, Instituto Euro-Americano de Educação, Ciência e Tecnologia, Belém, PA, Brazil

5 Programa de Biologia Estrutural, Instituto de Bioquímica Médica Leopoldo de Meis, Centro de Ciências da Saúde, Universidade Federal do Rio de Janeiro, Rio de Janeiro, RJ, Brazil

6 Instituto Nacional de Ciência e Tecnologia de Biologia Estrutural e Bioimagem, Rio de Janeiro, RJ, Brazil

7 Departamento de Bioquímica, Instituto Biomédico, Universidade Federal do Estado do Rio de Janeiro, Rio de Janeiro, RJ, Brazil adsorption phase suppresses infection by poliovirus strains Mahoney [2] and Sabin type I [3], coxsackievirus A16 [4], enterovirus A71 [5], and echovirus 6 [6] by restricting host cell entry. BLf sterically impedes receptor binding and/or competitively blocks interaction with sulfated glycosaminoglycans (GAGs), which might act as coreceptors or 'concentrating receptors' prior to the interaction with the specific virus receptor(s) that internalise the virus [7]. In a few instances, a post-adsorptive role of BLf has been reported, ranging from inhibition of echovirus 6 and enterovirus A71 uncoating [5, 8] and suppression of virus-induced apoptosis [9] to relatively minor unspecified intracellular effects on poliovirus Mahoney infection [2]. An in vivo protective role of BLf has been shown for mice challenged with a lethal dose of enterovirus A71 [5].

The above-mentioned effect of BLf has also been investigated in respiratory tract infections such as those caused by severe acute respiratory syndrome coronavirus and adenovirus type 2, showing impairment of viral infection in vitro $[10,11]$. However, rhinoviruses (RV), which are important seasonal respiratory pathogens and a primary cause of the common cold [12], with more than 170 types, were nearly overlooked, even after the observation that some types can exploit GAGs as cellular (co)receptors [13].

RVs belong to the genus Enterovirus, and the species Rhinovirus $A$ and Rhinovirus $B$ can be divided, according to their cellular receptor, into a major group and a minor group, using intercellular adhesion molecule 1 (ICAM-1) and lowdensity-lipoprotein receptor (LDLR), respectively. Members of the more recently established species Rhinovirus $C$ use 
cadherin-related protein 3 as a receptor. BLf has been proposed to interfere with heparan sulfate and LDLR during the first steps of Japanese encephalitis virus infection, with a negative effect on infection [14]. The critical role of sulfated GAGs was confirmed by treatment of host cells with sodium chlorate prior to infection [15]. However, no interaction with viruses using ICAM-1 as a receptor has been described so far.

Following entry by receptor-mediated endocytosis along diverse pathways [16], the native RV particle (N; VP1-VP4 + RNA) is first converted to a subviral A particle (VP1VP3 + RNA) and then to a subviral B particle (VP1-VP3). Depending on the RV receptor group, the N-to-A particle conversion is triggered by host-cell receptor binding and facilitated by the low endosomal $\mathrm{pH}$ (major group), or exclusively by the acidic environment of the endosome (minor group). The latter was evaluated by using inhibitors of the vacuolar $\mathrm{H}^{+}$-ATPase (V-ATPase) or ammonium chloride, which consistently decreased uncoating of various RVs [17].

In this work, we evaluated the antiviral effect of BLf on different stages of infection by RV-B14 (an ICAM-1-binding, major-group virus) in addition to investigating the cellular distribution of BLf over time, concomitant with virus internalisation.

\section{Material and methods}

\section{Cell culture and virus}

$\mathrm{H} 1-\mathrm{HeLa}$ cells were cultured as monolayers in DMEM (Sigma-Aldrich, USA) supplemented with $10 \%$ foetal bovine serum (FBS, Thermo Fisher Scientific, USA) and $50 \mu \mathrm{g}$ of gentamicin (Sigma-Aldrich, USA) per $\mathrm{ml}$ in a $5 \% \mathrm{CO}_{2}$ humid atmosphere at $37^{\circ} \mathrm{C}$. For experiments with the virus, the incubator was set to $34{ }^{\circ} \mathrm{C}$. The RV-B14 isolate used in this work was propagated and purified as described [18]. The purified RV-B14 used in the particle stability thermal release assay (PaSTRy) was donated by Dieter Blaas (Max Perutz Laboratories, Medical University of Vienna, Vienna Biocenter, Austria).

\section{Bovine lactoferrin (BLf)}

Native BLf (30\% iron saturation) containing capsules were purchased from Life Extension (USA). The capsules were dissolved in phosphate-buffered saline (PBS, $\mathrm{pH} 7.4$ ) at 25 ${ }^{\circ} \mathrm{C}$, and insoluble excipient material was removed by centrifugation at 5,000 rpm for $10 \mathrm{~min}$, followed by the transfer of the supernatant to a fresh tube. The last two steps were repeated five times. The final supernatant was passed through a $0.2-\mu \mathrm{m}$ filter, its concentration adjusted to $100 \mathrm{mg}$ $\mathrm{ml}^{-1}$ with PBS, and aliquots were stored at $4{ }^{\circ} \mathrm{C}$. BLf was labelled with FITC following a previously described protocol [19]. The native BLf used in PaSTRy and the lactoferrin binding assay was obtained from Art'Gerecht (Frankfurt, Germany). A freshly prepared $4 \mathrm{mg} \mathrm{ml}^{-1}$ solution in PBS was used for each assay.

\section{Cell viability assay}

Cells cultivated in 24-well plates (TPP, Switzerland) to 90\% confluence were incubated with increasing concentrations of $\operatorname{BLf}\left(0,0.25,0.5,1.0,2.0\right.$, and $\left.3.0 \mathrm{mg} \mathrm{m}^{-1}\right)$ in infection medium (IM; high-glucose DMEM supplemented with $2 \%$ FBS, $30 \mathrm{mM} \mathrm{MgCl}$ and $50 \mu \mathrm{g}$ of gentamicin per ml) for 5 days at $34{ }^{\circ} \mathrm{C}$. On day 5 , cells were stained for $1 \mathrm{~h}$ with crystal violet solution $(0.2 \%$ [w/v] crystal violet, $150 \mathrm{mM}$ $\mathrm{NaCl}$, and $1 \%[\mathrm{v} / \mathrm{v}]$ formaldehyde). Subsequently, wells were extensively washed with water, and plates were scanned using an Odyssey CLx Imaging System (LI-COR, USA). As an additional test to evaluate cell viability, we measured the ATP content of cells grown to $90 \%$ confluency in 96-well plates and incubated them as described above in the presence of CellTiter-Glo (Promega Corporation, USA) according to the manufacturer's protocol. For each condition, the detection threshold was determined by addition of Triton X-100 directly to the wells (final concentration, $1 \%$ ), followed by incubation for 2 hours at $34{ }^{\circ} \mathrm{C}$. Both experiments were performed in three independent biological replicates, and the results were plotted and analysed using Prism 6 software (GraphPad, USA), showing the mean and standard deviation (Supplementary Fig. 1).

\section{Plaque reduction assay}

The concentration of BLf used in the plaque reduction assay $\left(1 \mathrm{mg} \mathrm{ml}^{-1}\right)$ was selected based on the concentration used in the aforementioned work on BLf and enteroviruses, which ranged from $3 \mu \mathrm{g} \mathrm{ml}^{-1}$ to $3 \mathrm{mg} \mathrm{ml}^{-1}$. The approximate BLf concentration was employed in the H1-HeLa cell viability assay (Supplementary Fig. 1).

The plaque reduction assay was performed as described previously [20]. For the pre-adsorption assay, cells were incubated with $1 \mathrm{mg} \mathrm{ml}^{-1} \mathrm{BLf}$ in IM for $60 \mathrm{~min}$ at $34{ }^{\circ} \mathrm{C}$, washed with PBS, and incubated for $15 \mathrm{~min}$ at $4{ }^{\circ} \mathrm{C}$ with 50 plaque-forming units (PFU) of RV-B14 in IM per well to allow binding to the cells. The cells were kept at $34{ }^{\circ} \mathrm{C}$ for $60 \mathrm{~min}$ to trigger virus internalisation, washed, and covered with semisolid medium $(0.8 \%$ carboxymethylcellulose in IM). For the adsorption assay, cells were incubated with RV-B14 plus $1 \mathrm{mg} \mathrm{ml}^{-1}$ BLf in IM for $15 \mathrm{~min}$ at $4{ }^{\circ} \mathrm{C}$, followed by $60 \mathrm{~min}$ at $34{ }^{\circ} \mathrm{C}$ in the continuous presence of BLf, washed with PBS, and covered with semisolid medium. For the post-adsorption assay, cells were incubated with RV-B14 diluted in IM for 15 min at $4{ }^{\circ} \mathrm{C}$ 
and kept at $34{ }^{\circ} \mathrm{C}$ for $60 \mathrm{~min}$. The medium was replaced by $1 \mathrm{mg} \mathrm{ml}^{-1} \mathrm{BLf}$ in IM, and the cells were incubated at $34{ }^{\circ} \mathrm{C}$ for an additional $60 \mathrm{~min}$, washed with PBS, and covered with semisolid medium. For testing the effect on all steps combined, cells were incubated with $1 \mathrm{mg} \mathrm{ml}^{-1}$ BLf in IM for 60 min, washed with PBS, incubated with RV-B14 in IM plus $1 \mathrm{mg} \mathrm{ml}^{-1} \mathrm{BLf}$ for $15 \mathrm{~min}$ at $4{ }^{\circ} \mathrm{C}$, and kept at $34{ }^{\circ} \mathrm{C}$ for another $60 \mathrm{~min}$. Cells were washed with PBS, incubated with $1 \mathrm{mg} \mathrm{ml}^{-1} \mathrm{BLf}$ at $34{ }^{\circ} \mathrm{C}$ for 60 min, washed again with PBS and covered with semisolid medium, after which the cells were incubated for 5 days at $34{ }^{\circ} \mathrm{C}$ and stained with $1 \%$ crystal violet solution. Plaque reduction due to BLf treatment was compared to the control condition without BLf but otherwise conducted identically, and the number of plaques was taken to represent $100 \%$ infection. To reach about 50 PFU of RV-B14 per well, we added $72 \mathrm{TCID}_{50}$ by equating $1 \mathrm{TCID}_{50}$ to 0.69 PFU [21]. Three independent biological replicates were performed for each condition. Mean values with error bars equivalent to \pm 1 standard error (SE) are shown in the bar chart. Differences in the mean were evaluated by ANOVA with Sidak's multiple comparisons using Prism 6 software and were considered statistically significant for $p$-values $\leq 0.05$.

\section{Direct evaluation of the effect of BLf on RV-B14 entry}

The assay was performed as described previously [18]. In brief, cells ( $80 \%$ confluent) were incubated with RV-B14 $(\mathrm{MOI}=100)$ in the presence or absence of $1 \mathrm{mg} \mathrm{ml}^{-1} \mathrm{BLf}$ in IM for $15 \mathrm{~min}$ at $4{ }^{\circ} \mathrm{C}$, followed by $30 \mathrm{~min}$ at $34{ }^{\circ} \mathrm{C}$. Cells were washed with cold PBS, fixed with $3.8 \%$ formaldehyde in PBS, washed with PBS, and permeabilised in PBS with $0.1 \%$ Triton $\mathrm{X}-100$. The fixed cells were again washed with PBS and processed at room temperature as follows: The samples were incubated with blocking buffer (5\% BSA and $0.05 \%$ Tween-20 in PBS) for $2 \mathrm{~h}$, followed by immunolabeling with rabbit anti-RV-B14 serum in blocking buffer (1:1000 dilution) for $1 \mathrm{~h}$. After washing with PBS, cells were incubated with IRDye 680RD donkey anti-rabbit secondary antibody (LI-COR, USA) diluted in blocking buffer (1:2000 dilution) for $1 \mathrm{~h}$. Nuclei were stained with $0.1 \%$ DAPI (Thermo Fisher Scientific, USA) in PBS for $10 \mathrm{~min}$. Cells were then visualised under an LSM 510 Meta confocal fluorescence microscope (Zeiss, Germany). Nuclear staining and the bright-field channel were used to localise the cells. RV-B14 foci were counted manually for every cell present in 10 different fields in three separate preparations and plotted, and the statistical significance of differences in the mean of treated and untreated cells was analysed using Student $t$-test in Prism 6 software.
Kinetics of BLf entry into cells and its dependence on sulfated GAGs

When the cells reached $60 \%$ confluence, the medium was replaced by DMEM enriched with $2 \%$ FBS plus $50 \mathrm{mM}$ sodium chlorate $\left(+\mathrm{NaClO}_{3}\right)$ or without sodium chlorate $\left(-\mathrm{NaClO}_{3}\right)$, and the cells were incubated at $37{ }^{\circ} \mathrm{C}$ for 24 h. They were then washed and incubated with $1 \mathrm{mg} \mathrm{ml}^{-1}$ FITC-labelled BLf in DMEM containing 2\% FBS +/- 50 mM sodium chlorate for 10 (T10), 30 (T30), or 60 (T60) min. Control cells (-BLf) were treated similarly to T60, but without the addition of FITC-labelled BLf. Cells were fixed as above and incubated with $0.1 \%$ Hoechst 33342 (Thermo Fisher Scientific, USA) in PBS for 10 min. Cells from 10 randomly picked fields (containing 5 to 10 cells per field) from two independent experiments for each condition were imaged using an LSM 510 Meta confocal fluorescence microscope. A representative field for each condition is shown.

\section{Tracking of RV-B14 and BLf during the early events of entry into cells}

Cells were incubated with RV-B14 $(\mathrm{MOI}=20)$ and $1 \mathrm{mg}$ $\mathrm{ml}^{-1}$ FITC-labelled BLf in IM for $15 \mathrm{~min}$ at $4{ }^{\circ} \mathrm{C}$ and then at $34{ }^{\circ} \mathrm{C}$ for an additional 5 or $15 \mathrm{~min}$. The cells were then washed with PBS, fixed, permeabilised, and incubated with blocking solution as described above. Next, the cells were immunolabeled with rabbit anti-RV-B14 primary antiserum (1:1000 dilution) for $1 \mathrm{~h}$, incubated with IRDye 680RD donkey anti-rabbit secondary antibody (1:2000 dilution) for $1 \mathrm{~h}$, and stained with $0.1 \%$ DAPI in PBS for 10 min. Cells were then visualised on an LSM 510 Meta fluorescence confocal microscope.

\section{PaSTRy}

PaSTRy was performed as described [22] using a BioRad CFX Connect Real-Time PCR instrument to detect the SYTO-82 (Thermo Fisher Scientific, USA) signal, indicating viral RNA accessibility. Purified RV-B14 (0.5 $\left.\mathrm{mg} \mathrm{ml}^{-1}\right)$ was incubated with SYTO-82 $(5 \mu \mathrm{M})$ in PBS $+/-\operatorname{BLf}\left(0.25,0.5\right.$, and $\left.1.0 \mathrm{mg} \mathrm{ml}^{-1}\right)$ in $70 \mu \mathrm{l}$ at the given final concentrations. Each measurement was carried out in triplicate $(20 \mu \mathrm{l})$, and the RFU values were averaged to minimise measurement errors (technical replicates). The mean fluorescence (RFU) from two independent measurements was determined, and the corresponding first derivative was calculated and smoothed using GraphPad Prism 6. 


\section{Lactoferrin binding assay}

The assay was performed to determine (sub)viral particle binding to immobilised BLf in clear flat-bottomed highbinding 96-well plates (Corning, Sigma-Aldrich, USA). Plates were coated with $0.1 \mathrm{mg}$ of BLf in PBS ( $\mathrm{pH}$ 7.4) per well at $4{ }^{\circ} \mathrm{C}$ overnight. Positive control wells contained 10 $\mu \mathrm{g}$ of purified RV-B14 diluted in PBS per well instead of BLf and were incubated as above. Plates were washed with PBS to remove unbound BLf (and RV-B14) and blocked with $10 \%$ bovine serum albumin (BSA) for $2 \mathrm{~h}$ at $37{ }^{\circ} \mathrm{C}$. Subsequently, plates were washed with PBS and (except for the positive control wells) incubated with $10 \mu \mathrm{g}$ of purified RV-B14 (native) per well or a similar amount of subviral particles (A or B particles) in PBS for $1 \mathrm{~h}$ at $34{ }^{\circ} \mathrm{C}$. The A particles were generated by incubation of purified RV-B 14 $(10 \mu \mathrm{g})$ with $100 \mu \mathrm{l}$ of $100 \mathrm{mM}$ sodium acetate buffer $(\mathrm{pH}$ 5.6) for 10 minutes at room temperature. The generated subviral particles were washed five times with PBS using Amicon Ultra Filters (Sigma-Aldrich, USA) for reneutralisation. The $\mathrm{B}$ particles were generated by heating purified $\mathrm{RV}-\mathrm{B} 14(10 \mu \mathrm{g})$ to $56{ }^{\circ} \mathrm{C}$ for $10 \mathrm{~min}$ [22]. After washing with 1\% BSA in PBS-T (PBS containing 0.05\% Tween-20), plates were incubated with rabbit anti-RV-B14 serum [18] diluted (1:200) in PBS-T containing $1 \%$ BSA at $34{ }^{\circ} \mathrm{C}$ for 1 $\mathrm{h}$. The plates were then washed and incubated with DyLight 800-conjugated anti-rabbit antibody (Thermo Fisher Scientific, USA) diluted 1:500 in PBS-T containing 1\% BSA at $34{ }^{\circ} \mathrm{C}$ for $1 \mathrm{~h}$. After washing, the plates were scanned using an Odyssey CLx Imaging System for fluorescence emission using the $800 \mathrm{~nm}$ channel. Each sample RFU was averaged from four wells to minimise measurement errors (technical replicates). A representative plate and a bar chart from three independent replicates displaying the respective mean values with error bars equivalent to \pm 1 standard deviation (SD) are shown. Differences in the mean were evaluated by ANOVA with Sidak's multiple comparisons using Prism 6 software.

\section{Results}

To test the effect of BLf on infection by the major-group virus RV-B14, we performed a plaque reduction assay by adding BLf at different steps of the infection cycle: preadsorption, adsorption, post-adsorption, and all steps (Fig. 1a). The strongest plaque reduction was observed when BLf was present during adsorption $(\sim 52 \%)$ and throughout (all steps; $\sim 60 \%$ ), with no statistically significant difference between the two treatments. However, both were significantly different from the more modest but consistent plaque reduction of $\sim 30 \%$ in the pre-adsorption and post-adsorption schemes, while no statistically significant difference was found between those two latter schemes.
The substantial plaque reduction observed when BLf was present at the start of the infection, comparable to its continuous presence (the all-steps scheme), indicated that it predominantly interfered with an early step of the viral life cycle. This was further corroborated by confocal microscopy analysis of virus internalisation. RV-B14 at an MOI of 100 was attached to cells in the cold for $15 \mathrm{~min}$ in the presence or absence of BLf. Endocytosis was then triggered by warming the cells to $34^{\circ} \mathrm{C}$, and intracellular viral capsid proteins were detected $30 \mathrm{~min}$ post-entry by indirect immunofluorescence. This showed the presence of several bright foci within the infected cells (Fig. 1b), which most likely represented virusloaded vesicles, as reported previously [18]. Quantification of foci in multiple cells revealed that the presence of BLf resulted in a decrease in RV-B14 entry by $\sim 44 \%$ (Fig. 1c). Since virtually no surface-associated virus was detected, the result confirmed our hypothesis that BLf prominently acts during cell entry by significantly blocking virus attachment, but not its endocytosis once it is bound to the cells.

Based on the above results, we next (indirectly) assessed whether BLf might perturb the interaction between the RV-B14 and its receptor, ICAM-1 [23]. By preventing the attachment to its main surface target, sulfated GAGs [19] (e.g., heparan sulfate presented by various proteoglycans), we evaluated whether some BLf remains bound to proteins expressed in HeLa cells, including ICAM-1. We achieved this by abolishing GAG sulfation by incubating the cells for $24 \mathrm{~h}$ with sodium chlorate. Then, cell monolayers were incubated with FITC-labelled BLf for 10, 30, and $60 \mathrm{~min}$, and the fluorescent signal was visualised by confocal microscopy (Fig. 2). Untreated control cells demonstrated an even distribution of BLf over the cell membrane at $10 \mathrm{~min}$, followed by uptake and accumulation in the perinuclear region (juxtaposed to or within the cis-Golgi region) at $30 \mathrm{~min}$ and 60 min post-binding, respectively. In stark contrast, no fluorescence was detectable after pretreatment with sodium chlorate, suggesting that BLf attachment to the cell membrane is critically dependent on the presence of sulfated GAGs. This result consequently ruled out a direct interaction between BLf and ICAM-1 on the HeLa cell membrane and thus competition with RV-B14 for binding to its entry receptor. The inhibitory effect of BLf on virus binding might therefore instead be due to steric hindrance by GAG-immobilised BLf decorating proteoglycans in the vicinity of ICAM-1, with residual binding/internalisation perhaps mediated by hypothetical coreceptors or 'concentrating receptors'.

As approximately $56 \%$ of the RV-B14 escaped being blocked by the presence of BLf during adsorption (Fig. 1b, c), we wondered whether uptake of BLf and simultaneous infection with RV-B14 would result in their colocalisation, thereby perhaps also interfering with subsequent stages, e.g., uncoating. This might then account for the slightly stronger effect of BLf in the plaque reduction assay (when 
Fig. 1 BLf affects RV-B14 infection primarily by interfering with cell entry. (a) Plaque reduction assay performed using H1-HeLa cells infected with RV-B14 and incubated with BLf at different steps of the infection: pre-adsorption, adsorption, post-adsorption, and all steps. (b) Identification of intracellular RV-B14 foci at $30 \mathrm{~min}$ postinfection in H1-HeLa cells incubated with $1 \mathrm{mg} \mathrm{ml}^{-1} \mathrm{BLf}$ (+BLf) during virus adsorption. In the control (-BLf), BLf was not included. The panel shows representative confocal images, depicting RV-B14 particles (green) located intracellularly and detected using specific antibodies. The cell nucleus was labelled with DAPI (blue). (c) Quantification of virus foci per cell in the absence (empty bar) or presence (full bar) of BLf from 10 different fields of view in three separate preparations. *, $p<0.05$; NS, not statistically significant
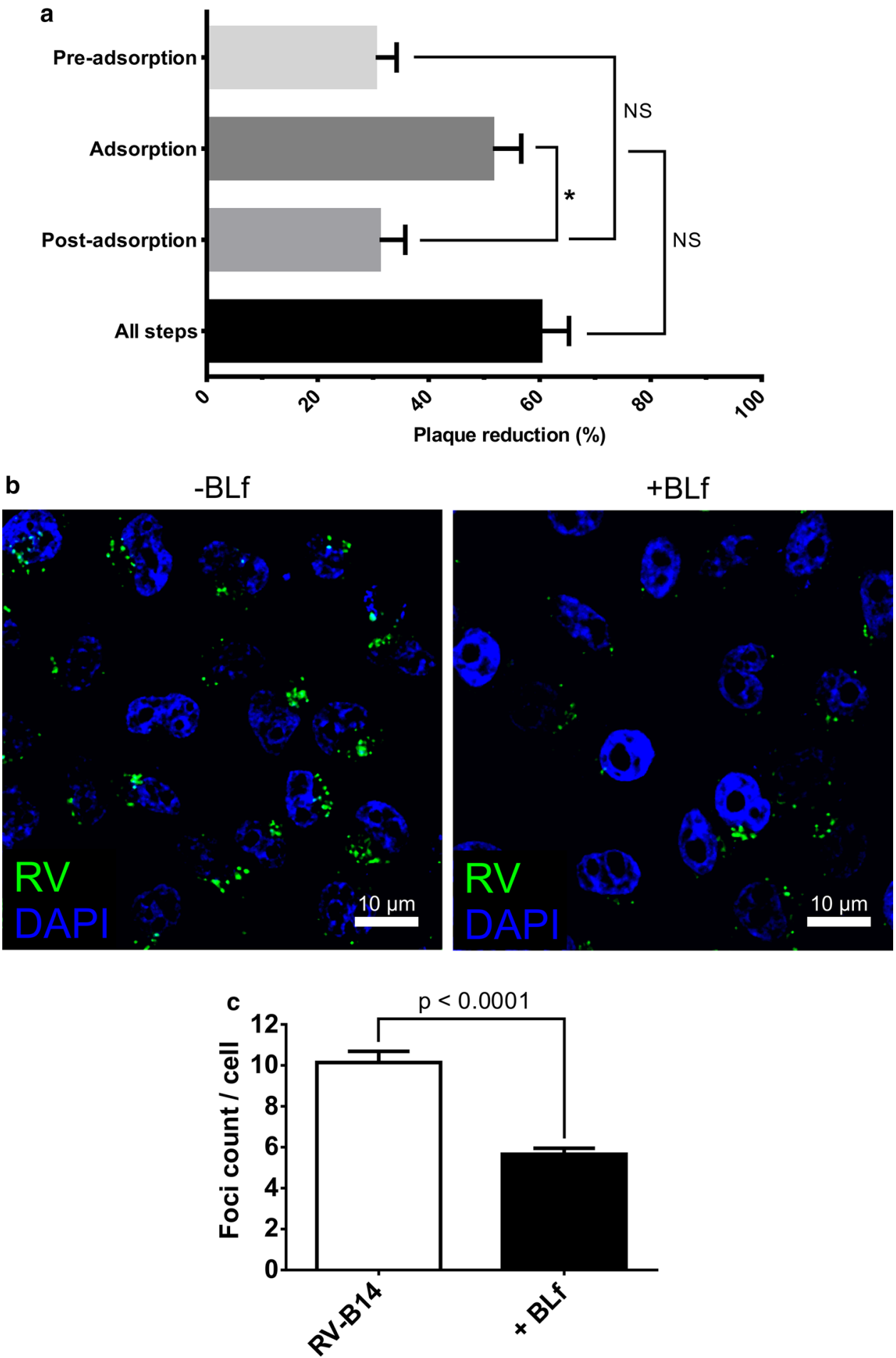

present during adsorption or throughout) when compared to its effect on virus attachment (see above). To answer this question, we tracked RV-B14 and BLf during cell entry by fluorescence imaging of FITC-labelled BLf and RV-B14 (detected using a rabbit anti-RV-B14 serum followed by IRDye 680RD-labeled secondary antibody) at 5 and 15 min post-binding (Fig. 3a). We observed a non-uniform colocalisation in elongated cytoplasmic vesicles (resembling sorting endosomes - upper panel inset) at 5 min postbinding, which largely persisted at 15 min post-binding in mostly round vesicles (resembling endosomal carrier vesicles - lower panel insets). Some RV-B14-containing vesicles did not colocalise with BLf, which was more evident at 15 min post-binding (white arrowheads). Because of this 

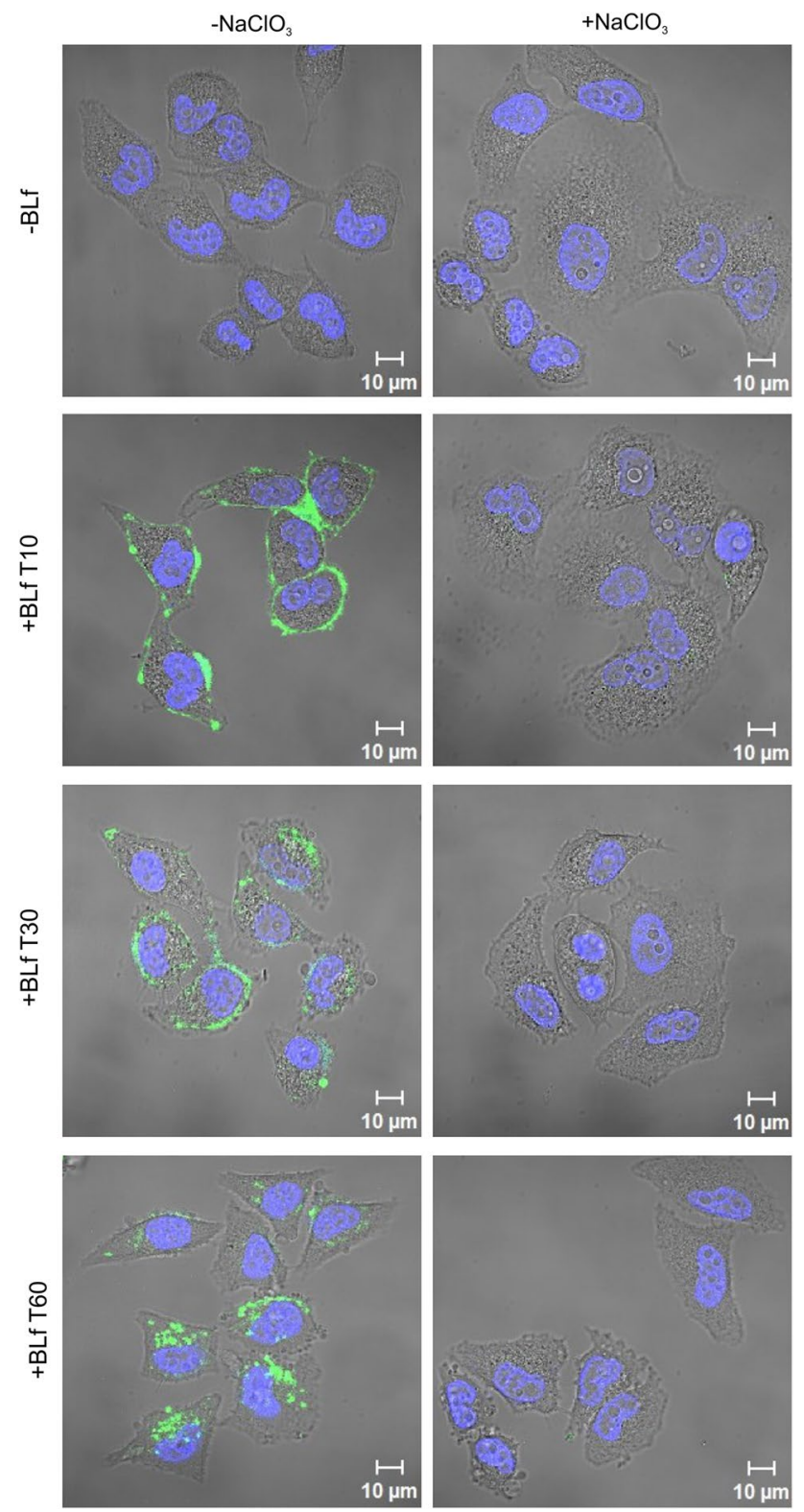

Fig. 2 Binding and internalisation of BLf in H1-HeLa cells is dependent on the sulfation of GAGs. The role of GAG sulfation in the cellular binding of BLf was assessed by incubating the cells with conventional medium $\left(-\mathrm{NaClO}_{3}\right)$ or medium supplemented with 50 $\mathrm{mM}$ sodium chlorate $\left(+\mathrm{NaClO}_{3}\right)$ for $24 \mathrm{~h}$ before adding fresh medium (-BLf panels) or $1 \mathrm{mg} \mathrm{ml}^{-1}$ FITC-labelled BLf (+BLf panels) to the cells. The kinetics of BLf entry were determined by recording the fluorescent signal at 10,30, and 60 min post-incubation. Representative fields depicting FITC-labelled BLf (green) and labelled nuclei (blue) are shown

considerable colocalisation of internalised RV-B14 with BLf, we also evaluated a direct action of BLf on RV-B14 uncoating intermediates, namely A and B particles. A direct interaction between BLf and $\mathrm{N}$ in vitro using an ELISAbased assay was not detected, in line with the PaSTRy experiment (Supplementary Fig. 2), nor was an interaction detected with A particles (Fig. 3b). Unexpectedly, however, we detected significant binding of B particles to BLf, although this is unlikely to be relevant for the uncoating of this virus.

\section{Discussion}

Here, we demonstrate a distinct antiviral effect of BLf on infection of H1-HeLa cells by the major-group rhinovirus RV-B14. The interference with infectivity was highest when BLf was added to the cells together with the virus and maintained throughout the experiment (all steps), resulting in a $\sim 60 \%$ drop in plaque formation. Insignificantly less reduction in plaque formation $(-52 \%)$ was observed when BLf was present only during virus attachment and endocytic uptake (adsorption). The extent of this inhibition is comparable to previous results with poliovirus [2, 3].

Immunofluorescence analysis demonstrated a $44 \%$ decrease in intracellular fluorescent foci, representing viruscontaining vesicles [18], most likely resulting from inhibition of RV-B14 binding to the host cells. This effect consequently accounts for most of the plaque reduction under comparable conditions. Direct competition with ICAM-1 is unlikely to occur, as the elimination of cellular sulfation in HeLa cells via sodium chlorate treatment reduced the binding of fluorescently labelled BLf to the plasma membrane to undetectable levels, implicating sulfated GAGs as a main binding site. Additionally, no BLf internalisation was observed. Notably, HeLa cells express LDLR [24, 25], which is known to bind and internalise lactoferrin amongst several other ligands $[14,26]$. Interestingly, chylomicron remnants were found to require prior binding to GAGs for subsequent transfer to LDLR, mediating their endocytosis into HepG2 cells. Heparinase treatment completely abolished their attachment to these cells [27]. We therefore speculate that BLf likewise requires initial binding to GAGs for subsequent shuttling to LDLR to explain the nearly complete loss of surface-associated fluorescent BLf from chlorate-treated HeLa cells. Our suggestion that RV-B14 could interact with the cell membrane regardless of the presence of ICAM-1 (e.g., via hypothetical coreceptors or 'concentrating receptors') is corroborated by the observation of binding of RV-B14 to COS-7 cells lacking ICAM-1 [28]. Other researchers demonstrated that competition between membrane-bound RV-B14 (on HeLa cells) and anti-ICAM-1 antibody removed only $80 \%$ of the virus, even when using $0.4 \mathrm{mg} \mathrm{ml}^{-1}$, a very high concentration of the antibody [23]. Both observations highlight the possibility of RV-B14 interacting with membranes without the assistance of the main receptor, which is in agreement with RV-B14-binding being competitively inhibited by sulfated GAG binding BLf or by steric hindrance of ICAM-1. 
Fig. 3 RV-B14 and BLf share similar entry routes but lack a direct interaction when probed in vitro. (a) $\mathrm{H} 1-\mathrm{HeLa}$ cells were incubated with RV-B14 and 1 $\mathrm{mg} \mathrm{ml}^{-1}$ FITC-labelled BLf, and entry was imaged by confocal fluorescent microscopy at 5 (upper panels) and 15 (lower panels) min post-adsorption.

The left panels are bright-field images, showing cell morphology and cell borders, and the middle panels and the insets in the right panels show the fluorescence signals of the RV-B14-specific antibodies (red) and FITC-labelled BLf (green) merged (individual fluorescent channels are shown in Supplementary Fig. 3). (b) BLf $(0.1 \mathrm{mg})$ was immobilised to a 96-well plate overnight and subsequently incubated individually with native RV-B14 and A and B particles. (Sub)viral particle interaction was detected by immunofluorescence and quantified using ImageJ. Representative results (left) and mean and standard deviation quantification of three independent assays (right) are presented. As a positive control, one plate was incubated with RV-B14 overnight instead of BLf and processed similarly
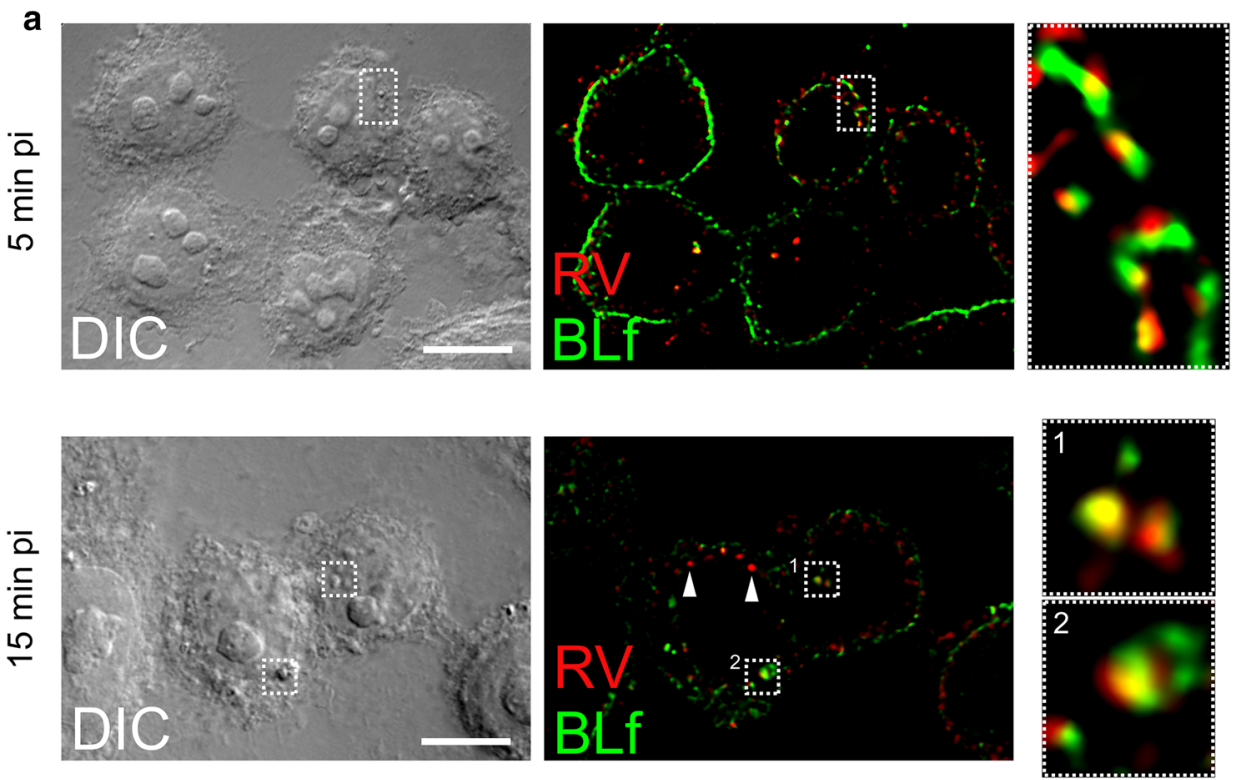

b
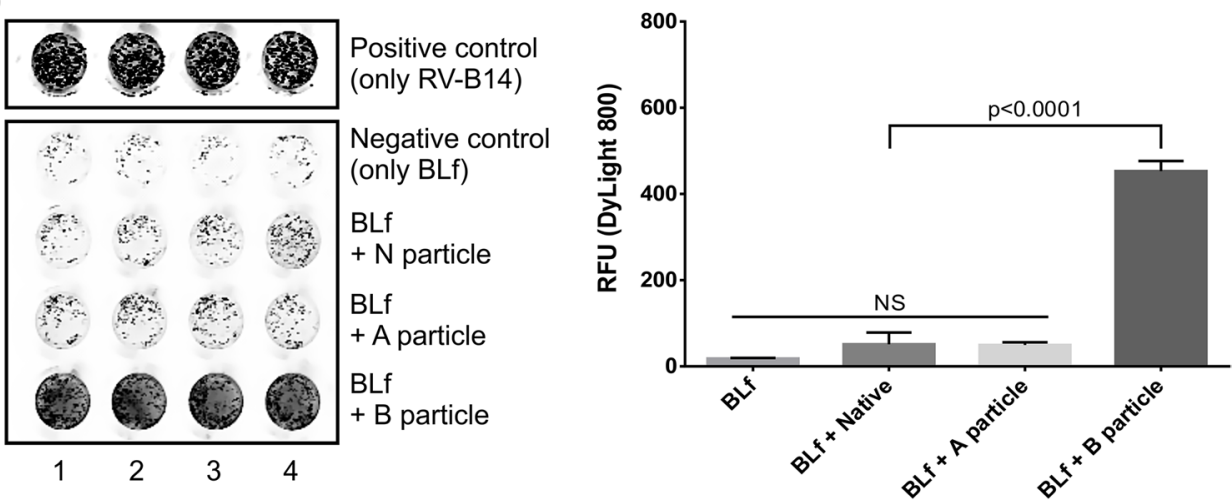

Cointernalisation of RV-B14 and FITC-labelled BLf demonstrated that, within the internalised fraction, some virus colocalised with BLf, presumably resulting from an occasionally shared entry pathway, as ICAM-1 binding RVs can enter HeLa cells via multiple pathways, as seen for RV-B14 and RV-A89 [29]. Direct association between virions and BLf, when located in the same vesicle, could potentially contribute to reduced infectivity. RV-B14 uncoating is complete at 15 min pi [18], notably, at a time when this colocalisation becomes rather pronounced. However, our in vitro assay did not indicate a direct interaction between RV-B14 $\mathrm{N}$ and $\mathrm{A}$ particles at neutral $\mathrm{pH}$, similar to what has been observed for echovirus 6 [8]. However, in the same publication, Ammendolia et al. demonstrated that echovirus 6 could bind BLf exclusively at low $\mathrm{pH}(<6)$, which is found in endosomal carrier vesicles. This supports our colocalisation data obtained at $15 \mathrm{~min}$ pi and might suggest an additional effect of BLf via interference with uncoating.

The BLf binding assay revealed that (empty) B particles could interact with immobilised BLf. To generate B particles, the RNA must be ejected, possibly through a hole opening via loss of one or more pentamers [30], giving immobilised BLf access to the external and internal faces of the free pentamers and increasing the likelihood of BLf interaction. This favours a putative interaction between BLf and viral structural proteins and suggests that virus translation and/or assembly could be additional targets of BLf. Furthermore, the above presents a reasonable explanation for the observed $\sim 30 \%$ plaque reduction when BLf was present before or after virus attachment/entry, as seen for other enteroviruses [2, 5, 8], including RV-A2 (an LDLR-binding minor-group virus), where the addition of BLf ( $1 \mathrm{mg} \mathrm{ml}^{-1}$ ) 30 min prior to RV-A2 adsorption caused $10 \%$ plaque reduction [31]. The latter study, however, in contrast to our analysis with the major-group RV-B14, did not evaluate the effect of BLf during adsorption and post-adsorption.

Taken together, our results indicate that BLf acts mainly at the plasma membrane, presumably via steric hindrance by binding to sulfated GAGs, such as members of the syndecan family. The target(s) of its slight post-binding effect remain(s) to be identified. 
Supplementary Information The online version contains supplementary material available at https://doi.org/10.1007/s00705-021-04993-4.

Acknowledgements We are grateful to Dr. Eurico Arruda for the donation of H1-HeLa cells, and Dr. Thomas Smith and Dr. Dieter Blaas for the donation of RV-B14. We wish to thank Dr. Heinrich Kowalski and Dr. Dieter Blaas for critically examining the manuscript and giving valuable comments and suggestion for improving the text. This study is dedicated to the memory of Prof. Dr. Franklin Rumjanek.

Author contributions Conceptualisation: CBD, CAMC, AMOG, RBG. Methodology: CBD, ARH, CAMC. Validation: ARH, AMOG, RBG. Formal analysis: CBD, ARH. Investigation: CBD. Resources: ARH, AMOG, RBG. Data curation: CBD, AMOG. Writing - original draft preparation: CBD, ARH. Writing - review and editing: ARH, CAMC. Visualisation: ARH. Supervision: AMOG, RBG. Project administration: AMOG, RBG. Funding: AMOG, RBG

Funding Open access funding provided by Medical University of Vienna. This work was funded by grants from the National Council for Scientific and Technological Development (CNPq) (to Andre Marco de Oliveira Gomes and Rafael Braga Gonçalves) and Fundação Carlos Chagas Filho de Apoio a Pesquisa do Estado do Rio de Janeiro (FAPERJ) (to Andre Marco de Oliveira Gomes).

Availability of data and material All datasets presented in this study are included in the article/supplementary material.

\section{Compliance with ethical standards}

Conflict of interest The authors declare that they have no conflict of interest.

Open Access This article is licensed under a Creative Commons Attribution 4.0 International License, which permits use, sharing, adaptation, distribution and reproduction in any medium or format, as long as you give appropriate credit to the original author(s) and the source, provide a link to the Creative Commons licence, and indicate if changes were made. The images or other third party material in this article are included in the article's Creative Commons licence, unless indicated otherwise in a credit line to the material. If material is not included in the article's Creative Commons licence and your intended use is not permitted by statutory regulation or exceeds the permitted use, you will need to obtain permission directly from the copyright holder. To view a copy of this licence, visit http://creativecommons.org/licenses/by/4.0/.

\section{References}

1. van der Strate BW, Beljaars L, Molema G, Harmsen MC, Meijer DK (2001) Antiviral activities of lactoferrin. Antivir Res 52(3):225-239. https://doi.org/10.1016/s0166-3542(01)00195-4

2. Marchetti M, Superti F, Ammendolia MG, Rossi P, Valenti P, Seganti L (1999) Inhibition of poliovirus type 1 infection by iron-, manganese- and zinc-saturated lactoferrin. Med Microbiol Immunol 187(4):199-204. https://doi.org/10.1007/s004300050093

3. McCann KB, Lee A, Wan J, Roginski H, Coventry MJ (2003) The effect of bovine lactoferrin and lactoferricin B on the ability of feline calicivirus (a norovirus surrogate) and poliovirus to infect cell cultures. J Appl Microbiol 95(5):1026-1033. https://doi.org/ 10.1046/j.1365-2672.2003.02071.x
4. Lin TY, Chu C, Chiu CH (2002) Lactoferrin inhibits enterovirus 71 infection of human embryonal rhabdomyosarcoma cells in vitro. J Infect Dis 186(8):1161-1164. https://doi. org/10.1086/343809

5. Weng TY, Chen LC, Shyu HW, Chen SH, Wang JR, Yu CK, Lei HY, Yeh TM (2005) Lactoferrin inhibits enterovirus 71 infection by binding to VP1 protein and host cells. Antivir Res 67(1):31-37. https://doi.org/10.1016/j.antiviral.2005.03.005

6. Pietrantoni A, Ammendolia MG, Tinari A, Siciliano R, Valenti P, Superti F (2006) Bovine lactoferrin peptidic fragments involved in inhibition of Echovirus 6 in vitro infection. Antivir Res 69(2):98106. https://doi.org/10.1016/j.antiviral.2005.10.006

7. Boulant S, Stanifer M, Lozach PY (2015) Dynamics of virusreceptor interactions in virus binding, signaling, and endocytosis. Viruses 7(6):2794-2815. https://doi.org/10.3390/v7062747

8. Ammendolia MG, Pietrantoni A, Tinari A, Valenti P, Superti F (2007) Bovine lactoferrin inhibits echovirus endocytic pathway by interacting with viral structural polypeptides. Antivir Res 73(3):151-160. https://doi.org/10.1016/j.antiviral.2006.09.002

9. Tinari A, Pietrantoni A, Ammendolia MG, Valenti P, Superti F (2005) Inhibitory activity of bovine lactoferrin against echovirus induced programmed cell death in vitro. Int $\mathbf{J}$ Antimicrob Agents 25(5):433-438. https://doi.org/10.1016/j.ijantimica g.2005.02.011

10. Lang J, Yang N, Deng J, Liu K, Yang P, Zhang G, Jiang C (2011) Inhibition of SARS pseudovirus cell entry by lactoferrin binding to heparan sulfate proteoglycans. PLoS ONE 6(8):e23710. https ://doi.org/10.1371/journal.pone.0023710

11. Di Biase AM, Pietrantoni A, Tinari A, Siciliano R, Valenti P, Antonini G, Seganti L, Superti F (2003) Heparin-interacting sites of bovine lactoferrin are involved in anti-adenovirus activity. $\mathrm{J}$ Med Virol 69(4):495-502. https://doi.org/10.1002/jmv.10337

12. Makela MJ, Puhakka T, Ruuskanen O, Leinonen M, Saikku P, Kimpimaki M, Blomqvist S, Hyypia T, Arstila P (1998) Viruses and bacteria in the etiology of the common cold. J Clin Microbiol 36(2):539-542

13. Fuchs R, Blaas D (2010) Uncoating of human rhinoviruses. Rev Med Virol 20(5):281-297. https://doi.org/10.1002/rmv.654

14. Chien YJ, Chen WJ, Hsu WL, Chiou SS (2008) Bovine lactoferrin inhibits Japanese encephalitis virus by binding to heparan sulfate and receptor for low density lipoprotein. Virology 379(1):143151. https://doi.org/10.1016/j.virol.2008.06.017

15. Su CM, Liao CL, Lee YL, Lin YL (2001) Highly sulfated forms of heparin sulfate are involved in japanese encephalitis virus infection. Virology 286(1):206-215. https://doi.org/10.1006/ viro.2001.0986

16. Conzemius R, Ganjian H, Blaas D, Fuchs R (2016) ICAM-1 binding rhinoviruses A89 and B14 uncoat in different endosomal compartments. J Virol 90(17):7934-7942. https://doi.org/10.1128/ JVI.00712-16

17. Nurani G, Lindqvist B, Casasnovas JM (2003) Receptor priming of major group human rhinoviruses for uncoating and entry at mild low-pH environments. J Virol 77(22):11985-11991. https:// doi.org/10.1128/jvi.77.22.11985-11991.2003

18. Real-Hohn A, Provance DW Jr, Goncalves RB, Denani CB, de Oliveira AC, Salerno VP, Oliveira Gomes AM (2017) Impairing the function of MLCK, myosin Va or myosin Vb disrupts Rhinovirus B14 replication. Sci Rep 7(1):17153. https://doi.org/10.1038/ s41598-017-17501-z

19. Carvalho CA, Sousa IP Jr, Silva JL, Oliveira AC, Goncalves RB, Gomes AM (2014) Inhibition of Mayaro virus infection by bovine lactoferrin. Virology 452-453:297-302. https://doi.org/10.1016/j. virol.2014.01.022

20. Wald J, Pasin M, Richter M, Walther C, Mathai N, Kirchmair J, Makarov VA, Goessweiner-Mohr N, Marlovits TC, Zanella I, Real-Hohn A, Verdaguer N, Blaas D, Schmidtke M (2019) 
Cryo-EM structure of pleconaril-resistant rhinovirus-B5 complexed to the antiviral OBR-5-340 reveals unexpected binding site. Proc Natl Acad Sci USA 116(38):19109-19115. https://doi. org/10.1073/pnas.1904732116

21. Mena JA, Ramirez OT, Palomares LA (2003) Titration of nonoccluded baculovirus using a cell viability assay. Biotechniques 34(2):260-262, 264. https://doi.org/10.2144/03342bm05

22. Real-Hohn A, Groznica M, Loffler N, Blaas D, Kowalski H (2020) nanoDSF: in vitro label-free method to monitor picornavirus uncoating and test compounds affecting particle stability. Front Microbiol 11:1442. https://doi.org/10.3389/fmicb.2020.01442

23. Colonno RJ, Callahan PL, Long WJ (1986) Isolation of a monoclonal antibody that blocks attachment of the major group of human rhinoviruses. J Virol 57(1):7-12. https://doi.org/10.1128/ JVI.57.1.7-12.1986

24. Marlovits TC, Abrahamsberg C, Blaas D (1998) Very-low-density lipoprotein receptor fragment shed from HeLa cells inhibits human rhinovirus infection. J Virol 72(12):10246-10250. https:// doi.org/10.1128/JVI.72.12.10246-10250.1998

25. Lee WM, Chen Y, Wang W, Mosser A (2015) Growth of human rhinovirus in H1-HeLa cell suspension culture and purification of virions. Methods Mol Biol 1221:49-61. https://doi. org/10.1007/978-1-4939-1571-2_5

26. Herz J, Qiu SQ, Oesterle A, DeSilva HV, Shafi S, Havel RJ (1995) Initial hepatic removal of chylomicron remnants is unaffected but endocytosis is delayed in mice lacking the low density lipoprotein receptor. Proc Natl Acad Sci USA 92(10):4611-4615. https://doi. org/10.1073/pnas.92.10.4611
27. Zeng BJ, Mortimer BC, Martins IJ, Seydel U, Redgrave TG (1998) Chylomicron remnant uptake is regulated by the expression and function of heparan sulfate proteoglycan in hepatocytes. J Lipid Res 39(4):845-860

28. Staunton DE, Merluzzi VJ, Rothlein R, Barton R, Marlin SD, Springer TA (1989) A cell-adhesion molecule, Icam-1, is the major surface-receptor for rhinoviruses. Cell 56(5):849-853. https ://doi.org/10.1016/0092-8674(89)90689-2

29. Ganjian H, Zietz C, Mechtcheriakova D, Blaas D, Fuchs R (2017) ICAM-1 binding rhinoviruses enter HeLa cells via multiple pathways and travel to distinct intracellular compartments for uncoating. Viruses. https://doi.org/10.3390/v9040068

30. Buchta D, Fuzik T, Hrebik D, Levdansky Y, Sukenik L, Mukhamedova L, Moravcova J, Vacha R, Plevka P (2019) Enterovirus particles expel capsid pentamers to enable genome release. Nat Commun 10(1):1138. https://doi.org/10.1038/s41467-01909132-x

31. Clarke NM, May JT (2000) Effect of antimicrobial factors in human milk on rhinoviruses and milk-borne cytomegalovirus in vitro. J Med Microbiol 49(8):719-723. https://doi. org/10.1099/0022-1317-49-8-719

Publisher's Note Springer Nature remains neutral with regard to jurisdictional claims in published maps and institutional affiliations. 